\title{
Sistem Informasi Geografis Tour Dan Travel Berbasis Android Di Kabupaten Tegal
}

\author{
Farijz Milzan $^{(1)}$, Rinta Kridalukmana ${ }^{(2)}$, Ike Pertiwi Windasari ${ }^{(2)}$ \\ Program Studi Sistem Komputer Fakultas Teknik Universitas Diponegoro \\ Jalan Prof. Sudharto, Tembalang, Semarang, Indonesia
}

\begin{abstract}
The development of a device move technology , facilitate human life in undergo kesehariannya .To progress, technology device move could determine the existence of users, find out which address want to intended, and give a route to the location.The use of devices movement for the district government tegal, and students tegal in particular made them in the visits to the agent travel and tourism tegal spread across the country .Needed a system that help you in seeking information on travel agent and tourist tegal especially for students and the tegal problems that hampered by the agent the location.

The geographic information system created using the Java programming language with SDK (Software Development Kit) Android and using MySQL and SQLite databases, the system is a client-server. The process of making and development of Geographic Information System using SDLC (Software Development Life Cycle) using prototyping life cycle. By using the life cycle of prototyping, the design can be quickly created and tested by users. Users can participate in helping the development of a system to provide feedback on the prototype that has been tried before, so that the system be made better. The result of design this program is a system for the geographic information on device move that would facilitate users in find information and to travel agent and tourist attractions contained in district tegal .Information systems geographical location use technology LBS ( location based service ), this technology allows users to find the location of travel agent and tourist destinations want to visited .This system will developed in a move that runs the android operating system.
\end{abstract}

Key Terms: Geographic Information Systems, Agent Travel and Tour, Mobile, Android.

\section{PENDAHULUAN}

Era teknologi informasi sudah semakin canggih yang menjadikan kemudahan menjadi faktor utama dalam semua bidang kehidupan dalam mengakses informasi. Di samping itu, perkembangan teknologi internet yang cukup pesat dengan kemudahannya diakses oleh semua kalangan masyarakat, menjadi faktor pendukung dari permintaan masyarakat dalam kemudahan pencarian informasi yang diinginkan.

Perkembangan yang sangat pesat saat ini membuat arus kebutuhan dalam dunia teknologi informasi turut berkembangan cepat. Internet sebagai salah satu media untuk mendapatkan informasi juga semangkin mudah diakses dari mana saja. Dengan berkembanganya teknologi internet, masyarakat semakin di mudahkan dalam melakukan segala macam fasilitas dan proses, salah satu contohnya adalah mencari lokasi Tour dan Travel di kota Tegal, dimana terkadang masyarakat umum sangat sulit mencari lokasi Tour dan Travel pada saat mereka ingin bepergian dan juga saat liburan tiba, khusus masyarakat yang berasal dari luar kota Tegal. Berdasarkan latar belakang diatas pada proyek tugas akhir ini dibuat sebuah program untuk memberikan solusi yaitu pencarian lokasi Tour dan Travel di kota Tegal yang diakses lewat Android. Dengan demikian sistem informasi geografis ini akan menampilkan semua lokasi Tour dan Travel di kota Tegal, diharapkan hasil dari sistem informasi geografis lokasi Tour dan Travel di kota Tegal dapat diakses lewat internet dengan menggunakan Android.

Kemajuan teknologi Informasi mengenai geografis semakin dibutuhkan oleh banyak kalangan masyarakat misalnya informasi jarak antar daerah, lokasi, fasilitas dan banyak informasi lainnya. Informasi tersebut diperlukan pengguna untuk berbagai keperluan seperti penelitian, pengembangan, perancangan wilayah serta manajemen sumber daya alam. Karena adanya geografis ini dapat membantu penyajian suatu peta yang lebih interaktif, dimana pengguna dapat mengakses informasi geografis yang lengkap hanya dengan menggunakan komputer, webbrowser dan jaringan internet. Maka untuk mendapatkan informasi itu semua diperlukan geographical information system (GIS) atau yang dikenal dengan sistem informasi geografis (SIG). Oleh sebab itu, penulis merancang suatu sistem untuk menyajikan informasi geografis. Dari uraian diatas penulis mengangkat judul 'Sistem Informasi Geografis Tour Dan Travel Berbasis Android Di Kabupaten Tegal'.

\section{DASAR TEORI}

A. Sistem Informasi Geografis (SIG)

Sistem Informasi Geografis (SIG) atau Geographic Information System (GIS) adalah sebuah sistem yang didesain untuk menangkap, menyimpan, memanipulasi dan menampilkan seluruh jenis data geografis.

Akronim GIS terkadang dipakai sebagai istilah untuk geographical information science atau geospatial information studies yang merupakan ilmu studi atau pekerjaan yang berhubungan dengan Geographic Information System. Dalam artian sederhana sistem 
informasi geografis dapat kita simpulkan sebagai gabungan kartografi, analisis statistik dan teknologi sistem basis data (database)

SIG tidak lepas dari data spasial, yang merupakan sebuah data yang mengacu pada posisi, obyek dan hubungan di antaranya dalam ruang bumi. Data spasial merupakan salah satu item dari informasi di mana di dalamnya terdapat informasi mengenai bumi termasuk permukaan bumi, di bawah permukaan bumi, perairan, kelautan dan bawah atmosfer $^{[1]}$.

\section{B. LBS (Location Based Service)}

Location Based Service (LBS) atau layanan berbasis lokasi adalah istilah umum yang digunakan untuk menggambarkan teknologi yang digunakan untuk menemukan lokasi perangkat yang kita gunakan. Dua unsur utama LBS adalah:

1) Location Manager (API Maps)

Menyediakan tools/source untuk LBS, Application Programming Interface (API) Maps menyediakan fasilitas untuk menampilkan, memanipulasi map/peta beserta feature-feature lainnya seperti tampilan satelit, street (jalan), maupun gabungannya. Paket ini berada pada com.google.android.maps.

2) Location Providers (API Location)

Menyediakan teknologi pencarian lokasi yang digunakan oleh device/perangkat. API Location berhubungan dengan data GPS (Global Positioning System) dan data lokasi real-time. API Location berada pada paket Android yaitu di dalam paket Android.Location. Dengan Location Manager, kita dapat menentukan lokasi kita saat ini, Track gerakan/perpindahan, serta kedekatan dengan lokasi tertentu dengan mendeteksi perpindahan $^{[2]}$.

\section{Android}

Sistem operasi Android dikembangkan pertama kali oleh perusahaan start-up bernama Android, Inc. Sejak dibeli Google, Android memiliki momentum untuk berkembang dan saat ini telah menjadi salah satu sistem operasi untuk ponsel dan gadget yang paling berpengaruh di dunia ${ }^{[3]}$.

Android adalah sistem operasi berbasis Linux yang digunakan untuk telepon seluler (mobile) seperti telepon pintar (smartphone) dan komputer tablet (PDA). Android menyediakan platform terbuka bagi para pengembang untuk menciptakan aplikasi mereka sendiri yang digunakan oleh bermacam peranti bergerak. Android kini telah menjelma menjadi sistem operasi mobile terpopuler di dunia. Perkembangan Android pada mulanya didirikan oleh Andy Rubin, Rich Miner, Nick Sears, dan Chris White pada tahun $2003^{[4]}$.

\section{Android SDK (Software Development Kit)}

Android SDK adalah tools API (Application Programming Interface) yang diperlukan untuk mulai mengembangkan aplikasi pada platform Android menggunakan bahasa pemrograman Java. Android merupakan subset perangkat lunak untuk ponsel yang meliputi sistem operasi, middleware dan aplikasi kunci yang di-release oleh Google. Saat ini disediakan Android SDK (Software Development Kit) sebagai alat bantu dan API untuk mulai mengembangkan aplikasi pada platform
Android menggunakan bahasa pemrograman Java. Sebagai platform aplikasi-netral, Android memberi kesempatan untuk membuat aplikasi yang kita butuhkan yang bukan merupakan aplikasi bawaan Handphone/Smartphone ${ }^{[2]}$.

\section{E. ADT (Android Development Tools)}

Android Development Tools adalah plugin yang didesain untuk IDE Eclipse yang memberikan kemudahan dalam mengembangkan aplikasi Android dengan menggunakan IDE Eclipse. Dengan menggunakan ADT untuk Eclipse akan memudahkan dalam membuat aplikasi project Android, membuat GUI aplikasi, dan menambahkan komponen-komponen yang lainnya, begitu juga untuk melakukan running aplikasi menggunakan Android DK melalui Eclipse. Dengan ADT juga dapat melakukan pembuatan paket Android (.apk) yang digunakan untuk distribusi aplikasi Android yang dirancang ${ }^{[2]}$.

\section{F. XML (eXtensible Markup Languange)}

XML adalah singkatan dari eXtensible Markup Languange. Bahasa markup adalah sekumpulan aturanaturan yang mendefinisikan suatu sintal-sintal yang digunakan untuk menjelaskan dan mendeskripsikan teks atau data dalam sebuah dokumen melalui penggunaan tag. Bahasa markup populer lainnya adalah HTML yang menggambarkan kepada browser web tentang bagaimana menampilkan format teks, data, dan grafik ke layar komputer ketika sedang mengunjungi sebuah situs web.

XML dikembangkan mulai tahun 1996 dan mendapatkan pengakuan dari W3C pada bulan Februari 1998. Teknologi yang digunakan pada XML sebenarnya bukan teknologi baru, tapi merupakan turunan dari SGML yang telah dikembangkan pada awal 80-an dan telah banyak digunakan pada dokumentasi teknik proyek-proyek berskala besar. Ketika HTML dikembangkan pada tahun 1990, para penggagas XML mengadopsi bagian paling penting pada SGML dan dengan berpedoman pada pengembangan HTML menghasilkan markup languange yang tidak kalah hebatnya dengan SGML ${ }^{[5]}$.

\section{G. Java}

Java, dalam ilmu komputer, merupakan bahasa pemrograman berorientasi objek yang diperkenalkan pada tahun 1995 oleh Sun Microsystem, Inc., sebuah industri perangkat lunak yang cukup besar di Amerika Serikat, yang saat Java diciptakan, proyeknya dipimpin oleh James Gosling. Nama Java diambil karena beberapa pemrogramnya terkesan oleh keindahan pulau Jawa di Indonesia serta kenikmatan kopinya. Java memungkinkan kita membuat program-program komputer dengan paradigma yang kita jumpai di dunia nyata yang sebenarnya. Paradigma yang dimaksud adalah "Pemrograman Berorientasi Objek" yang dalam bahasa aslinya disebut sebagai OOP (Object Oriented Programming). Kita dapat membuat program yang mencerminkan fakta sesungguhnya yang memang kita jumpai dalam kehidupan sehari-hari melalui Java. Sebagai contoh, kita dapat membuat kelas Mobil yang memiliki data/atribut (deskripsi lengkap tentang mobil itu), misalnya Warna dan Jumlah Pintu serta memiliki fungsi/metodis (apa yang dapat dilakukan oleh mobil itu), misalnya Maju, Mundur, Belok, dan sebagainya dengan menggunakan Java ${ }^{[6]}$. 


\section{H. $P H P$}

PHP merupakan suatu bahasa pemrograman sisi server yang dapat digunakan untuk membuat halaman web dinamis. Contoh bahasa yang lain adalah Microsoft Active Server Page (ASP) dan Java Server Page (JSP). Dalam suatu halaman HTML user dapat menanamkan kode PHP yang dieksekusi setiap kali halaman tersebut dikunjungi. Karena kekayaanya akan fitur yang mempermudah perancangan dan pemrograman web, PHP memiliki popularitas yang tinggi. Pengecekan survei popularitas dapat dilakukan pada alamat www.php.net/usage.php.

PHP adalah kependekan dari PHP: HyperText Preprocessor (suatu akronim rekursif) yang dibangun oleh Rasmus Lerdorf pada tahun 1984. Dahulu, pada awal pengembangannya PHP disebut sebagai kependekan dari Personal Home Page. PHP merupakan produk Open Source sehingga siapa saja dapat mengakses sumber kodenya, menggunakan, dan mengubahnya dengan gratis ${ }^{[7]}$.

\section{I. $M y S Q L$}

MySQL adalah suatu sistem manajemen basis data relasional (RDBMS-Relational Database Management System) yang mampu bekerja dengan cepat, kokoh, dan mudah digunakan. Contoh RDBMS lain adalah Oracle, Sybase. Basis data memungkinkan pengguna untuk menyimpan, menelusuri, mengurutkan, dan mengambil data secara efisien. Server MySQL yang akan membantu melakukan fungsionalitas tersebut. Bahasa yang digunakan oleh MySQL tentu saja adalah SQL-standar bahasa basis data relasional di seluruh dunia saat ini.

MySQL dikembangkan, dipasarkan, dan disokong oleh sebuah perusahaan Swedia bernama MySQLAB. RDBMS ini berada di bawah bendera GNU GPL sehingga termasuk produk Open Source dan sekaligus memiliki lisensi komersial. Apabila menggunakan MySQL sebagai basis data dalam suatu situs web, pengguna tidak perlu membayar. Akan tetapi, jika pengguna ingin membuat produk RDBMS baru dengan basis MySQL dan kemudian menjualnya, user wajib bertemu muka dengan lisensi komersial $^{[7]}$.

\section{J. JSON (JavaScript Object Notation)}

XML bukanlah satu-satunya sarana untuk pertukaran data, kini telah hadir JSON sebagai format baru untuk pertukaran data. XML mungkin lebih dulu populer dibanding JSON, tapi sebenarnya jika diadu, JSON lebih unggul dari XML. Mulai dari kecepatan, penulisan yang lebih gampang dan pengkodean untuk parsing yang lebih ringkas dan sederhana.

JSON (JavaScript Object Notation) sendiri adalah format pertukaran data yang ringan, mudah dibaca dan ditulis oleh manusia, serta mudah diterjemahkan dan dibuat oleh komputer. Format ini dibuat berdasrkan bagian dari Bahasa Pemrograman JavaScript, Standar ECMA-262 Edisi ke-3 Desember 1999. JSON merupakan format teks yang tidak bergantung pada bahasa pemrograman apapun karena menggunakan gaya bahasa yang umum digunakan oleh programmer keluarga $\mathrm{C}$ termasuk $\mathrm{C}, \mathrm{C}++, \mathrm{C}$, Java, JavaScript, Perl, Python, dan lain-lain. Oleh karena sifat- sifat tersebut, menjadikan JSON ideal sebagai bahasa pertukaran data ${ }^{[5]}$.

\section{PERANCANGAN SISTEM}

Gambar 1 dan gambar 2 merupakan diagram Use Case yang menggambarkan interaksi antara pengguna dengan sistem yang dirancang beserta fungsionalitas yang diberikan oleh sistem.

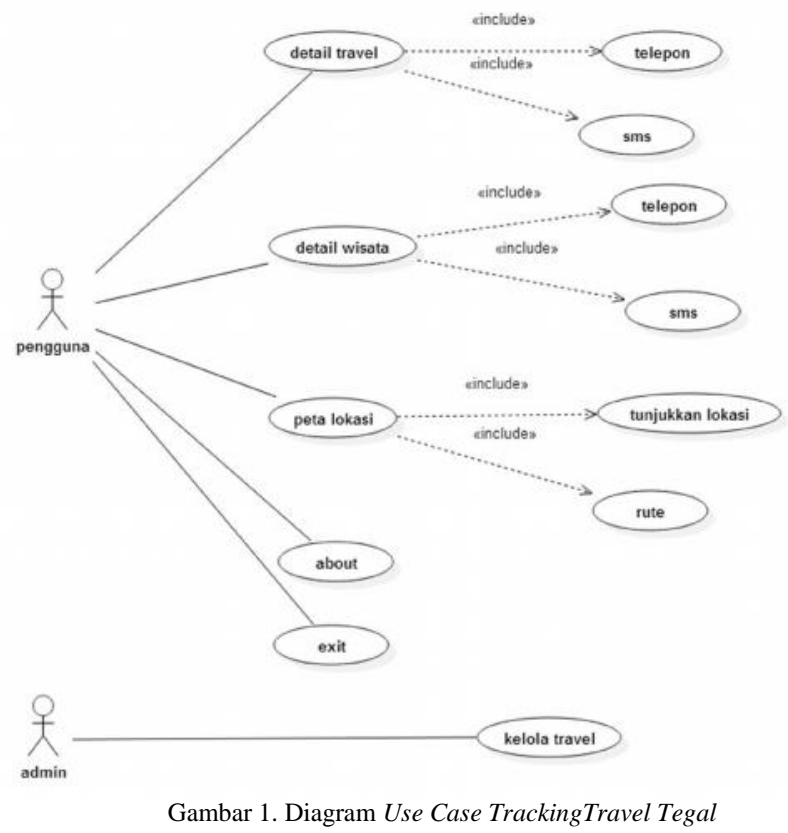

IV. IMPELEMENTASI DAN PENGUJIAN

A. Implementasi Google Maps APIv2

Pada aplikasi TrackingTravel Tegal penggunaan komponen peta dari Google Maps APIv2 merupakan hal yang mutlak. Google Maps API key harus disertakan dalam file manifest android project Saweue Syedara untuk dapat menggunakan komponen peta milik Google Maps. Google Maps API key bersifat unik, sehingga setiap pengembangan memiliki key masing-masing, apabila berbeda perangkat pengembangan maka key yang harus digunakan juga harus berbeda. Berikut merupakan kode sumbernya:

$<$ meta-data

android: name="com.google. android.gms.version" android:value="einteger/google_play_services_versi on" />

$<$ meta-data

android: name="Com.google.android.maps.v2.API KEY" android:value="AIzaSyCO9dM72TXVhHU3wOtRL88V wLi5ufsJkoY "/>

Pada kelas Activity dilakukan pemanggilan fragment, berikut merupakan kodenya:

gmap $=($ (SupportMapFragment $)$

get SupportFragmentManager () . findFragmentById (R.id. map)) . getMap ();

Kode sumber yang telah diimplementasikan pada kelas Activity akan menampilkan komponen peta milik Google Maps seperti ditunjukkan pada gambar di bawah ini. 


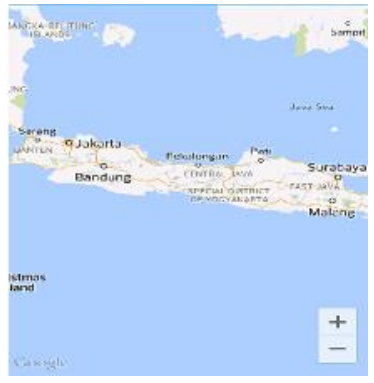

Gambar 3. Hasil Implementasi Google Maps APIv2

B. Pengujian Fungsionalitas Aplikasi TrackingTravel Tegal

Pengujian fungsionalitas aplikasi dilakukan untuk mengetahui apakah fungsi-fungsi dasar aplikasi telah dapat bekerja sesuai dengan yang diharapkan pada saat perancangan. Gambar hasil pengujian fungsionalitas aplikasi TrackingTravel Tegal ditunjukkan oleh gambargambar yang ada dibawah ini:

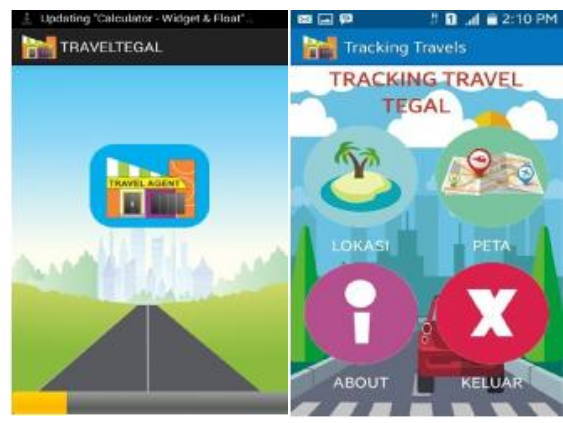

Gambar 4. Hasil pengujian fungsionalitas menu utama dan splash screen

Gambar 4 menunjukkan tampilan menu utama dan menu splash screen aplikasi TrackingTravel Tegal

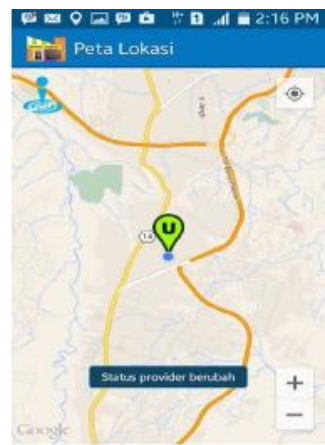

Gambar 5. Hasil pengujian fungsionalitas menu peta lokasi.

Gambar 5 menunjukkan tampilan menu peta lokasi pengguna berada di tempat yang di sesuaikan.

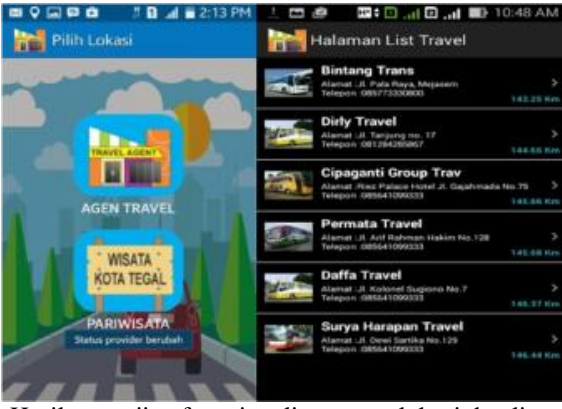

Gambar 6. Hasil pengujian fungsionalitas menu lokasi dan list agent travel

Gambar 6 menunjukkan tampilan pilih lokasi yang akan diklik salah satu, dalam halaman ini memilih sebuat agent travel dan hasilnya terdapat list travel yang akan pengguna pilih.

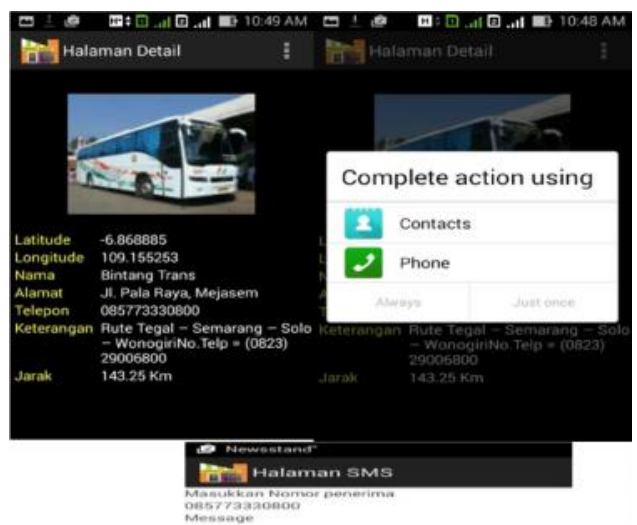

send sMs

Gambar 7. Hasil pengujian fungsionalitas menu detail travel, telepon dan sms

Gambar 7 memperlihatkan tampilan menu detail travel, telepon dan sms

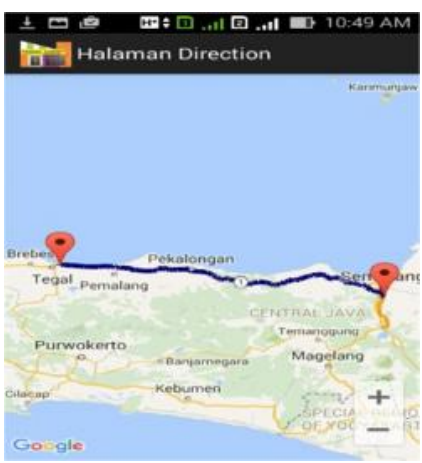

Gambar 8. Hasil pengujian fungsionalitas menu halaman direction travel Gambar 8 memperlihatkan tampilan menu jarak yang di tempuh pengguna. 


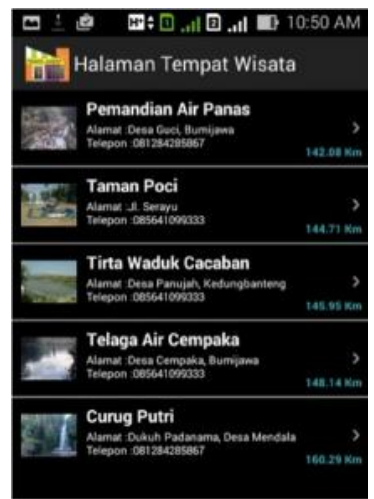

Gambar 9. Hasil pengujian fungsionalitas menu tempat wisata

Menu tentang lis tempat wisata (lihat gambar 9).
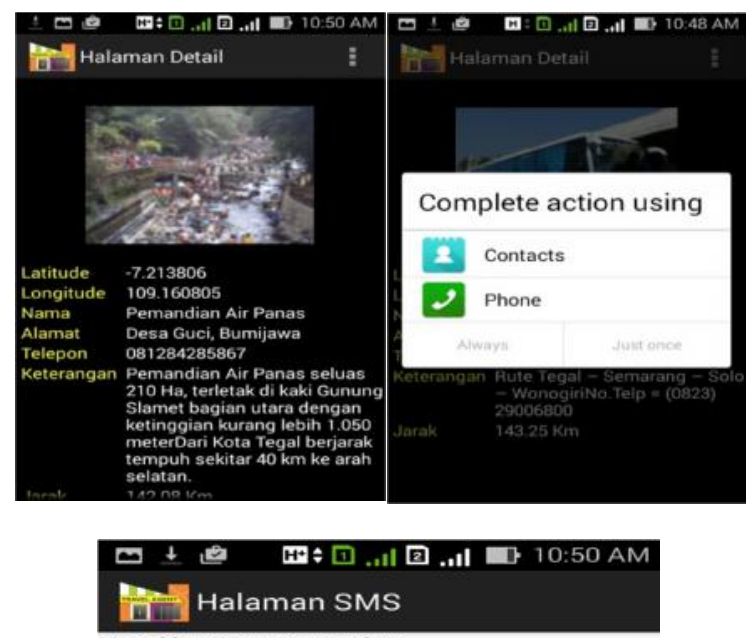

Masukkan Nomor penerima 081284285867 Message

\section{Send SMS}

Gambar 10. Hasil pengujian fungsionalitas menu detail wisata, telepon dan sms.

Gambar 10 menunjukkan tampilan menu detail wisata, telepon dan sms

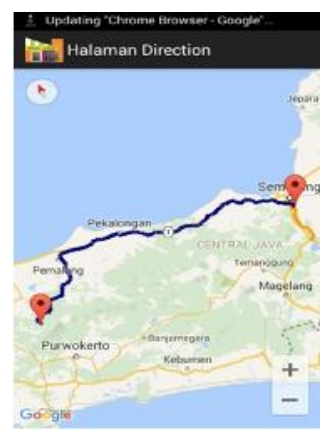

Gambar 11. Hasil pengujian fungsionalitas halaman direction wisata
Gambar 11 memperlihatkan tampilan menu direction atau jarak yang di tempuh sebuah pengguna untuk melakukan perjalanan.

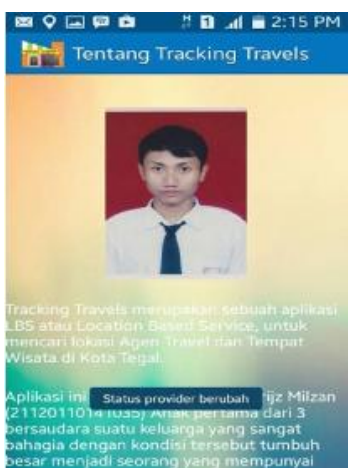

Gambar 12. Hasil pengujian fungsionalitas menu tentang

Gambar 12 memperlihatkan tampilan menu tentang pembuat serta deskripsi singkat aplikasi

\section{KESIMPULAN DAN SARAN}

\section{A. Kesimpulan}

Dari uraian dan proses pembuatan Tugas Akhir ini, penulis dapat menarik beberapa kesimpulan sebagai berikut:

1) Google Maps API merupakan komponen utama pada aplikasi Tracking Travel Tegal

2) Global Positioning System berperan penting dalam menentukan keakuratan posisi dari pengguna

3) Aplikasi Tracking Travel Tegal memberikan informasi mengenai lokasi yang terdapat di Kabupaten Tegal.

4) Aplikasi Tracking Travel Tegal bersifat publik, didistribusikan untuk umum, dapat diakses oleh siapa saja tanpa harus login.

5) Aplikasi Tracking Travel Tegal dapat bekerja dengan baik dalam lingkungan sesungguhnya, yaitu perangkat Asus Zenfone 5 dengan sistem operasi android versi 4.4.2 (KitKat) dengan Google APIs API Level 19.

\section{B. Saran}

Berdasarkan pengujian terhadap aplikasi TrackingTravel Tegal, dapat diberikan beberapa saran untuk pengembangan di masa depan sebagai berikut:

1) Basis data dalam aplikasi Tracking Travel Tegal ini baru mencakup wilayah Kabupaten Tegal, Indonesia.

2) Penggunaan Eclipse dalam membuat Sistem Informasi Geografis berbasis android harus mempertimbangkan masalah sumberdaya perangkat bergerak, terutama pada ukuran layar. Sebab ada banyak model smartphone dengan berbagai ukuran layar. Jadi dalam mendesain harus menyesuaikan ukuran layar yang paling kecil.

3) Aplikasi Tracking Travel Tegal hanya dapat dijalankan pada sistem operasi Android, aplikasi ini belum mendukung cross platform, pengembangan selanjutnya dapat dilakukan dengan mengembangkan aplikasi yang mendukung cross platform.

4) Perlu dilakukan penelitian lebih lanjut mengenai bagaimana membuat agar Sistem Informasi Geografis 
dapat diterapkan lintas sistem operasi seperti Blackberry dan iOS dengan menggunakan Eclipse.

\section{DAFTAR PUSTAKA}

[1] Irwansyah, Edy., SISTEM INFORMASI GEOGRAFIS : Prinsip Dasar dan Pengembangan Aplikasi, Digibooks, Yogyakarta, 2013.

[2] Safaat H, Nazruddin., PEMROGRAMAN APLIKASI MOBILE SMARTPHONE DAN TABLET PC BERBASIS ANDROID, Informatika Bandung, Bandung, 2012
[3] Jubilee Enterprise., Pemrograman Android untuk Pemula, PT Elex Media Komputindo, Jakarta, 2013

[4] Murya, Yosef., Pemrograman Android Black Box. Jasakom, 2014

[5] Dharma Kasman, Akhmad., Kolaborasi Dahsyat ANDROID dengan PHP dan MySQL, Penerbit Lokomedia, Yogyakarta, 2013.

[6] Nugroho, Adi., Algoritma dan Struktur Data dalam Bahasa Java, Penerbit ANDI, Yogyakarta, 2008.

[7] Nugraha Widhi Pratama, Antonius., CodeIgniter: CARA MUDAH MEMBANGUN APLIKASI PHP, mediakita, Jakarta Selatan, 2010. 